\title{
Drama to Instruct and Entertain: Literature and Performance for EFL students, EFL Dramatists and EFL Directors (Drama Instructors): Curriculum and Extra -curricular Activities
}

\author{
Walid Ali Zaiter \\ Department of Languages and Translation \\ Taibah University, Saudi Arabia
}

\begin{abstract}
While acting has always been a concern for dramatists and performers since the Greeks and Romans, it nevertheless plays and assumes more prominent roles up to the present day; for the dramatists and players, it is a play to write and to be performed on a stage; for students it is a play to read as literature and it becomes a text to analyze for academic evaluation-testing. This article argues that English as a foreign language (EFL) students, EFL dramatists and EFL directors can pair up to make English language learning, and teaching through drama an enjoyable learning experience. The process requires EFL dramatists to write topics related to students' culture, and curriculum designers should set clear goals to strengthen these aspects. By the same token students should feel drama as a vehicle of education for language learning. Thus, their potential for learning expands beyond their class or lecture to the extent that they look up at theatre as a venue of self learning the natural way. The paper would then recommend a one-act play to read and perform, inserted in the curriculum of teaching English as a means of learning and performing. Ultimately, students prospects be achieved following the measures proposed in the paper.
\end{abstract}

Keywords: EFL students, EFL dramatists, drama, theater, conventions, curriculum as a medium of teaching language skills through drama, to instruct and entertain

Cites as: Zaiter, W. A. (2019). Drama to Instruct and Entertain: Literature and Performance for EFL students, EFL Dramatists and EFL Directors (Drama Instructors): Curriculum and Extra curricular Activities. Arab World English Journal for Translation \& Literary Studies, 3 (3) 221232. DOI: http://dx.doi.org/10.24093/awejtls/vol3no3.18 